\title{
気候変動下の熱帯性低気圧による全球高潮の基礎的予測 \\ Basic Projection of Global Storm Surges due to Tropical Cyclones in the Climate Change
}

\author{
信岡尚道 $^{1}$
}

\section{Hisamichi NOBUOKA}

\begin{abstract}
One of fearful impacts to coastal zone in future is change in intensity of tropical cyclone on global warming. The purpose of this paper is projection of future storm surges due to the tropical cyclones and vulnerability assessments by the storm surges in coastal zones. Outputs of a global climate model were used for trend of change in the sea surfaced pressure of tropical cyclones. A numerical simulation was employed to project storm surges. Projected results showed future storm surges become higher along coasts of Gulf of Mexico and east coast of America, and East-Asian coasts facing to Pacific Ocean. The results of vulnerability assessment showed that change in intensity of tropical cyclone is big impact as same as impact of rise in sea level and population growth, particularly in Asia coastal zones.
\end{abstract}

\section{1. はじめに}

地球温暖化による全球規模の沿岸域の脆弱性評価は Hoozemans ら (1993) やNichollsら（1999）の研究には じまり，精度向上が進められている。本格的に熱帯低気 圧を取り入れはじめたのは，信岡ら（2009）の研究から になる. 地域スケールに絞れば近年, 気候モデルの出力 結果をもとにした熱帯低気圧の高潮研究がなされている が, 熱帯低気圧の表現に必要とされる解像度が十分でな い問題などにより, 予測された熱帯低気圧を用いて高潮 予測を行うと既往の高潮よりも小さくなることが多い. したがって熱帯低気圧を確率的なモデルで処理する方法 がしばしば用いられる（例えば，安田ら2010）。他方， 新たな防災の実行には数十年以上も時間を要する. 地球 温暖化に対する適応策の導入は国際的支援のもと途上国 で始まり出している。したがって, 沿岸域については地 球温暖化・気候変動による海面上昇とともに高潮の予測 が早急に必要な状態である。

本研究では全球を対象に, 気候モデルで出力された結 果のうち基本的な気候変動の要因を整理し, 地球温暖 化 ·気候変動下の基本的な熱帯低気圧の変化から高潮の 変化を示すことを目的とした。

\section{2. 方法}

\section{（1）高潮予測モデル}

50 年以上におよぶ熱帯低気圧を対象に全球の高潮を予 測するには膨大な CPU資源が必要となる。 まずCPU資源 を節約するため, 北西太平洋を対象に高潮数值モデルの 特性把握を行った.モデル構成の基本は信岡ら（2009）と 同じで水深積分型の平面 2 次元浅水方程式（式（1））を
差分法の1つADI法で解くものである.

本研究では新たに, 式（1）に移流加速度項を加え, 非線形性の効果および必要性について確かめた。同時に コリオリカの効果についても参考に調べた. そして全球 の高潮計算において, 非線形性および考慮のコリオリ力 を考慮すべきか判断をおこなった。

$$
\begin{aligned}
& \frac{\partial M}{\partial t}-2 \Omega N \sin \phi+\frac{g h}{R \cos \phi} \frac{\partial \eta}{\partial \lambda}=\frac{h}{\rho_{w} R \cos \phi} \frac{\partial p}{\partial \lambda}+\frac{\tau_{s}^{(\lambda)}}{\rho_{w}}-\frac{\tau_{b}^{(\lambda)}}{\rho_{w}} \\
& \frac{\partial N}{\partial t}+2 \Omega M \sin \phi+\frac{g h}{R} \frac{\partial \eta}{\partial \phi}=\frac{h}{\rho_{w} R} \frac{\partial p}{\partial \phi}+\frac{\tau_{s}^{(\phi)}}{\rho_{w}}-\frac{\tau_{b}^{(\phi)}}{\rho_{w}} \\
& \frac{\partial \eta}{\partial t}+\frac{1}{R \cos \phi} \frac{\partial M}{\partial \lambda}+\frac{1}{R \cos \phi} \frac{\partial N}{\partial \phi}(N \cos \phi)=0
\end{aligned}
$$

ここに $M, N$ は経度,緯度軸方向の流量, $\eta$ と $h$ は海水位 と全水深, $\Omega$ はコリオリ係数, $p$ は海面上の大気圧, $\tau_{s}$ と $\tau_{b}$ は海面と海底摩擦力, $\lambda$ と $\phi$ は経度と緯度座標, $R$ は地 球の半径, $g$ と $\rho_{w}$ は重力加速度と海水密度である.

（2）熱帯低気圧ベストトラックデータ

高潮計算に用いる熱帯低気圧について 3 種類のベスト トラック型データセットを準備した. 基本は北西太平洋 領域にはRSCM-TOKYOが提供するベストトラックデー 夕, その他の領域ではNOAAのWorld Data Center for Meteorology Ashevilleが提供する IBTrACS データである (現在気候)。それらの熱帯低気圧の中心気圧低下を $10 \%$ 大きくさせたものを将来気候の 1 つのデータセットとし た.もうひとつ、気象研究所の気候モデル出力から取り 出されたトラックデータから変化特性を求め中心気圧を 変化させたものを将来気候（2075-2099年）のものとし た. 新しい時間の中心気圧 $P_{D t+1}$ は元の時間の中心気圧 $P_{D}$ と時間変化量 $\Delta P_{D t}$ で表せるとする.

$$
p_{D t+1}=p_{D t}+\alpha(\text { lati, long }) \Delta p_{D t}
$$

基本となるべストトラックデータでは係数 $\alpha$ は全て 1 
であるが，この係数に地球温暖化による熱帯低気圧の変 化の影響を次に示すように取り込む.

気候モデル出力の熱帯低気圧ベストトラックデータ (時刻, 緯度経度座標值や中心気圧など) には, 現在気 候と将来気候のものが 25 年ずつある。まず，各時刻にお ける気圧值から時間当たりの気圧変化量を求めた．次に, 各時間デー夕を気圧上昇と気圧下降とで分離した（この 時点で時刻は意味を持たなくなっている). 分離された データの空間分布から曲線関数で平滑化を行い, 緯度経 度 1 度角の格子で時間当たりの気圧上昇量および気圧低 下量の分布を作成した。これらを現在気候と将来気候で それぞれ実施した。

作成された緯度経度 1 度角の格子における, 将来気候 の時間当たりの気圧変化量を同現在気候の気圧変化量で 除して気候変化率 $\alpha$ を求めることを, 気圧上昇と気圧低 下それぞれで行った。この気候変化率を式（2）を用い て，基本とする前述の観測されたベストトラックデータ に乗じることで比較的安定した中心気圧の将来気候デー タセットを作成した。これを言い換えると, これまで観 測された熱帯低気圧の発達や減衰が, 地球温暖化による 気候変動で地点ごとに平均的に変化すると予測できる傾 向を取り入れて, 熱帯低気圧の強大化を示すデー夕を作 成したことになる。

なお, 熱帯低気圧の中心から最大風速までの半径 (台風半径) については, 全域で加藤（2005）の式を適 用した。

\section{（3）全球の高潮脆弱性評価方法}

脆弱性評価のための高潮の計算は全球を 2 分角格子で 設定して，3つのデータセットに対して行った。

高潮浸水による沿岸域の浸水面積と浸水人口を, 南北 180 度, 東西 360 度の全球で 60 秒角格子に区切り計算を 行う。対象年は現在気候の 2000 年頃と将来気候の 2100 年頃である. 計算方法は基本的に信岡ら（2009）の方法 に準拠しているので，ここでは概要と変更点に重点を示 すにとどめる.

\section{a) 温暖化のシナリオ}

温室効果ガスの排出量により温暖化の度合いは変わ る. 将来人口も社会状態により変化する，IPCCでは，大 きくは温室効果ガスの排出量を中心とした「経済と環境」 および「国際協調の度合い」にわけた 4 大シナリオ （SRES Report）を作成している. 海面上昇も SRES シナ リオに基づいた気候モデルの結果から，気温上昇を元に 海水の熱膨張を計算し，さらに氷河の融解など他の要因 を加えて求められている. そのうち, 本研究で用いたシ ナリオは, A1B シナリオである.

熱膨張による海面上昇值には公開されているうちの MRI-CGCM2.3.2a（Yukimoto ら，2001）と MIROC3.2
（Hasumiら，2004）による結果を用い，IPCC-AR4に記載 されている海面上昇值と比較して他の要因分を補正した 海面上昇量を本研究で用いた。人口分布にはCIESINの GPW3（UN）を用いて簡易配分により60秒角格子へダ ウンスケーリングしたものを用いた。 人口成長率シナリ オには, SRES シナリオによる地域人口変化から各国人 口にダウンスケーリングしたCIESINの值を用いた。

\section{b）沿岸高潮と浸水計算}

陸上地形にはUSGSの GTOPO30 と NASAのSRTM30を 組み合わせ 60 秒角格子に変換したものを用いた。 60 秒角 格子で表現された海岸線に，2分角格子で算定された期 間最大高潮偏差に対して空間的に最も近い值をあてはめ た。高潮位は高潮偏差にさく望平均満潮位を加えたもの とした。この満潮位には Matsumotoら（2000）の海洋潮 汐モデルNAO.99bの中にある分潮の值から求めた.

浸水域の計算にはレベル堪水法を用い, 海岸線に沿っ た高潮高を外力として 60 秒角格子上での浸水域を算出し た.ここでは人工的な海岸防御施設を考慮していないの で, 求められる氾濫域は「潜在的高潮浸水域」となる. さらに浸水域と人口分布を重ねあわせ「潜在的高潮浸水 人口」を求めた.

\section{3. 高潮への非線形性とコリオリカの効果}

北西太平洋の中, 2 分角格子点であらわされた沿岸に おいて, 最高高潮に対する移流 (非線形性) の効果とコ リオリカの効果による水位への影響を, 累積分布関数で 表したものが図-1である。結果から，この格子間隔にお いては非線形性がほとんどの地点で無視してよいが，コ リオリカについては無視できないことにがわかる．北西 太平洋の中で，コリオリカが特に最高高潮に関係してい たのは中国南部とべトナム中部の沿岸であった。以降, この結果と CPU資源を考え，移流は除外した式（1）を 基礎とした数值モデルを利用して解析を進めた.

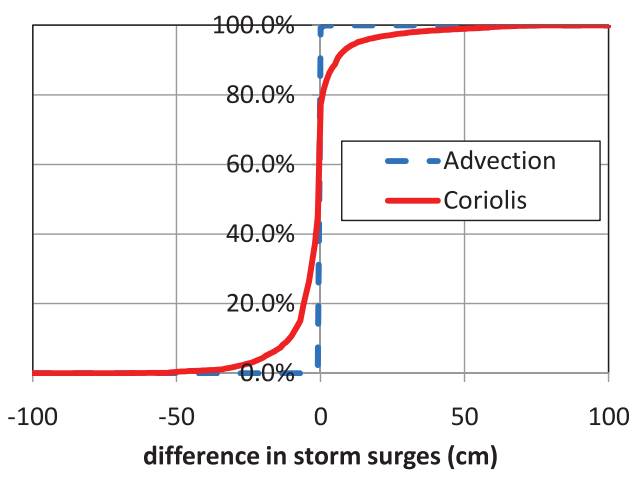

図-1 非線形性とコリオリ力の高潮偏差への影響 


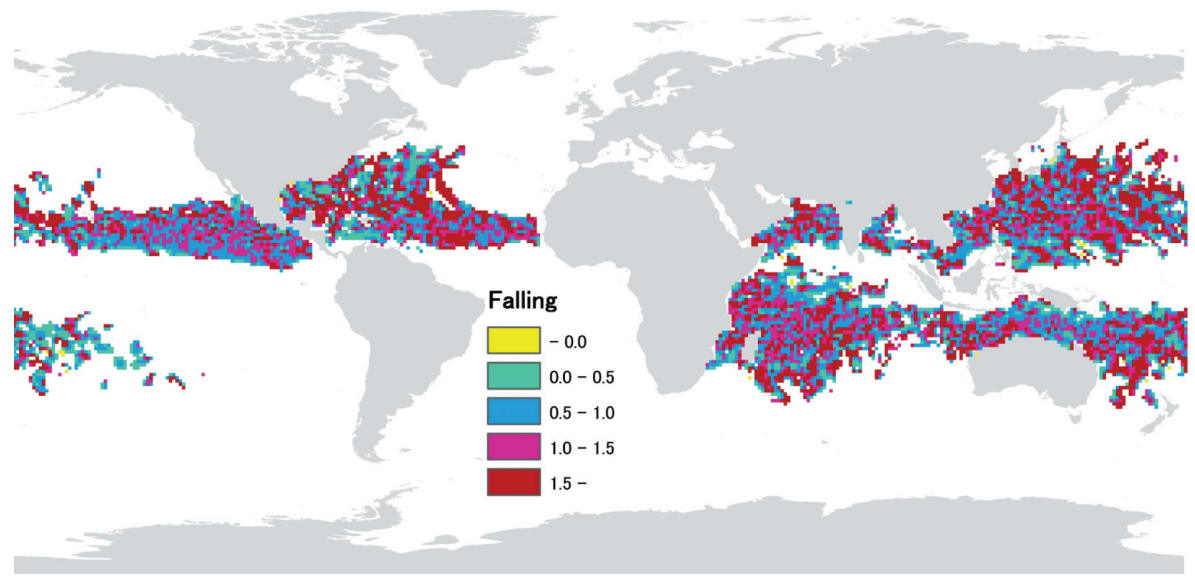

(a) 気圧低下

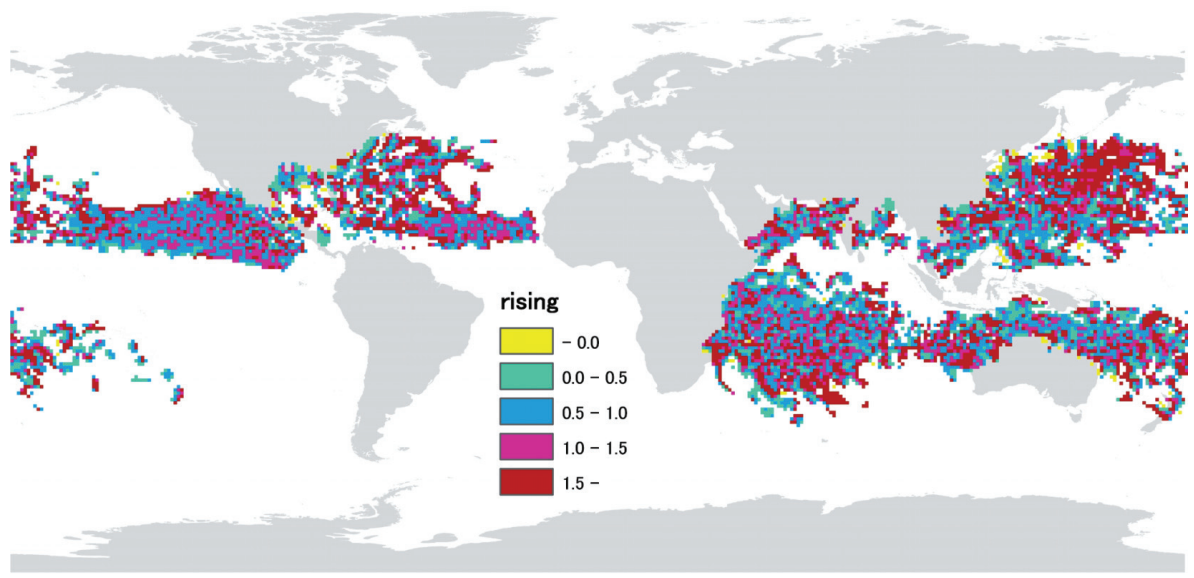

(b) 気圧上昇

図-2 熱帯低気圧の中心気圧の時間変化量の現在気候と将来気候の比

\section{4. 将来気候における熱帯低気圧の発達と減衰}

25 年間分の現在と将来気候実験結果の熱帯低気圧べス トトラックデータから, 熱帯低気圧の中心気圧の 1 時間 当たりの低下量と増加量について, 将来気候の現在気候 に対する比の全球分布を求めたものが図-2（a）と（b） である．前者は中心気圧が低下の場合で值が 1 より大き いと熱帯低気圧が現在気候よりも発達することを, 逆に 後者は中心気圧が上昇の場合で值が 1 より大きいほど熱 带低気圧が現在気候よりも減衰することを示している.

両図とも現在気候に対する中心気圧変化量の比が 1 よ り大きい地点と 1 より小さい地点が混在しており，傾向 がやや分かりづらいが，図-2(a) では比が 1.5 以上の非常 に発達しやすい場所がメキシコ湾を中心に見られ，それ 以外でも比が 1.0 以上の地点が多数みられる. 気圧減衰 を示す図-2（b）では，低緯度を中心に比が 1.0 以下の場 所が多数存在している．高緯度になると比が 1.0 以上の
場所が目立つが，これは将来の熱带低気圧が発達し最低 中心気圧が低下した後の減衰速度が現在よりも速いこと を示しているにすぎないと考えられる。

\section{5. 高潮偏差の変化}

高潮偏差の最大值に関し, 将来気候の值から現在気候 の值を引いた差，つまり将来気候への気候変動による高 潮の増減の全球分布を示したものが図-3である。ここで は有意な差を $0.25 \mathrm{~m}$ として考えると, アメリカのメキシ コ湾と東岸, 中国と韓国やべトナムなどアジア大陸の東 岸，イギリスで有意な差が沿岸の長い距離で起こること が推定された結果である. 図では小さい日本の沿岸の結 果を述べると, 東京湾、伊勢湾, 瀬戸内海西部や東北北 海道で有意な差が見られた。

緯度経度 1 分角格子での值を 1 度数として, $0.1 \mathrm{~m}$ 幅の 階級で, 高潮の差の度数分布を求めたものが図-4である. 縦軸は対数で表示している。この図には, 将来の熱帯低 


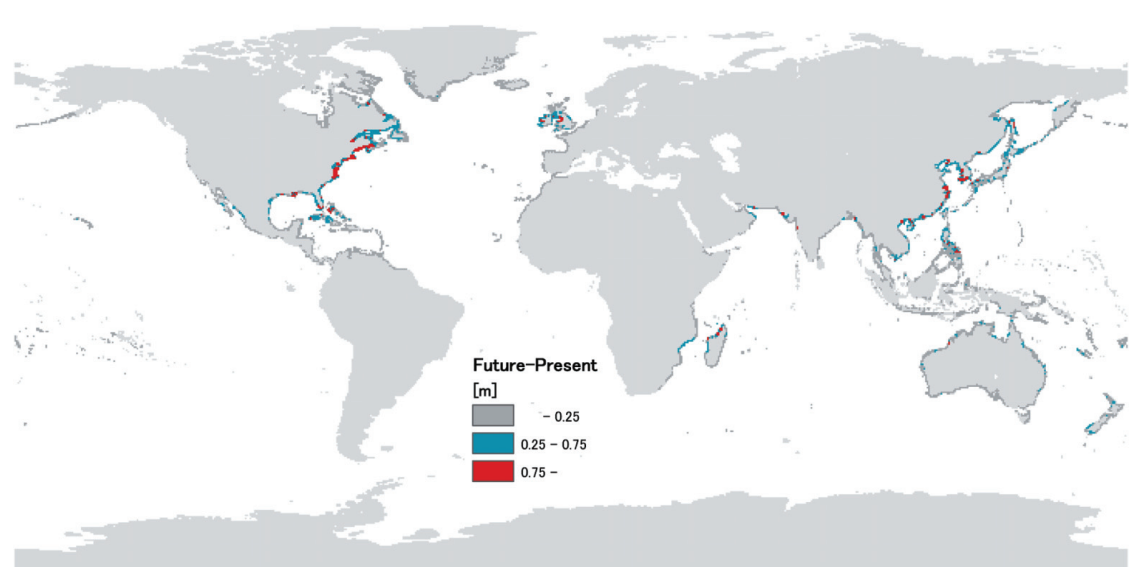

図-3 地球温暖化による高潮偏差の変化量の全球地図（解像度を30分メッシュに落としている）

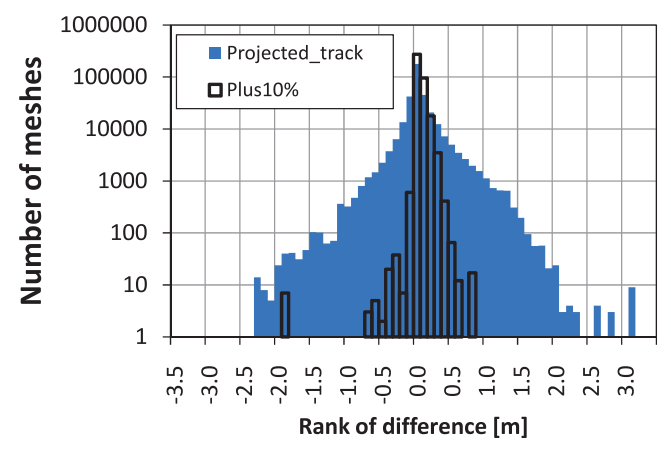

図-4 高潮偏差の変化量の度数分布

気圧が現在気候より中心気圧をさらに $10 \%$ 低下させた場 合の高潮の、現在気候高潮との差も同時に示している. 気候モデル出力結果から本研究で推定した将来熱帯低気 圧による高潮の変化は，現在に比べ低くなるところもあ るが全体としては，高くなる方が多いことがわかる．中 心気圧をさらに $10 \%$ 低下したケースでも，変化の幅は狭 くなるが同様の傾向がみられる．この研究においては, 中心気圧の低下に比例して台風半径が小さくなるように 仮定した計算を行っていることも負の值が出てくること に関係しているであろう，気候モデル出力結果の，考え られる高潮変化の幅が大きいことおよび負の值の主たる 要因は, 25 年分の気候モデル出力結果では十分ではない ことによる図-2のように気圧時間変化量に明確な傾向が 表れていないことが関係しているとも考えられる。した がって，局所域ごとに将来の高潮が高くなる、または低 くなるとの議論は本研究結果からはできない。気候モデ ル出力結果の期間を長くした結果を用いることが必要で ある。

\section{6. 脆弱性評価}

図-5 (a)，(b) は地域ごとに潜在的浸水面積と潜在的浸 水域人口が現在気候の 2000 年から将来気候の 2100 年まで に増加する量を示している. エラーバーは気候モデルに よる海面上昇量值の違いによるものである，将来気候に 打ける熱帯低気圧の中心気圧の変化に上る効果について は，この効果の有無による算定値の差から求めたもので ある。浸水面積には海面上昇が大きく効いており全球で 18 万 $\mathrm{km}^{2}$ ほど拡大する。 そのうち熱帯低気圧による効果 は全球で $12 \%$ 程度であるが，アジアでは $28 \%$ ほど占める.

浸水域人口には，海面上昇，熱帯低気圧の中心気圧の

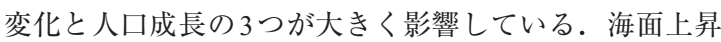
と人口成長のみを合算したものをSub_totalで，熱帯低気 圧の気圧変化までを考慮したものを Totalで表している. 両值の差がアジアで大きい、つまりアジアでは熱帯低気 圧の中心気圧の変化が浸水域人口にあたえる影響が大き い結果となった.

浸水面積と浸水域人口の各図ともに右側に中心気圧を さらに $10 \%$ 低下させた場合の結果を示している. 地域久 ケールで見た場合，気候モデル出力結果を用いた左図の Totalに近い值となっている.

\section{7. 結論}

全球の高潮数值計算において緯度経度 2 分角格子で行う なら移流項は無視できることを北西太平洋で確かめ地球 温暖化による脆弱性評価には移流項を除いて算定を実施 した．熱帯低気圧の中心気圧の時間変化量の将来変化に ついて気候モデル出力結果から求めた結果, 出力が 25 年 間であるため平滑化した平均的な量でみても「ばらつき」 は残ったが, 気候変動により将来気候でメキシコ湾や北 西太平洋などで気圧低下速度が大きくなる傾向が示せた. 


- Sea-level rise
$\square$ Change in Intencity of TC
- TOTAL
AS:ASIA
OC: OCEANIA
EU:EUROPE
AF:AFRICA
NA:North AMERICA
SA:South AMERICA
SA:South AMERICA

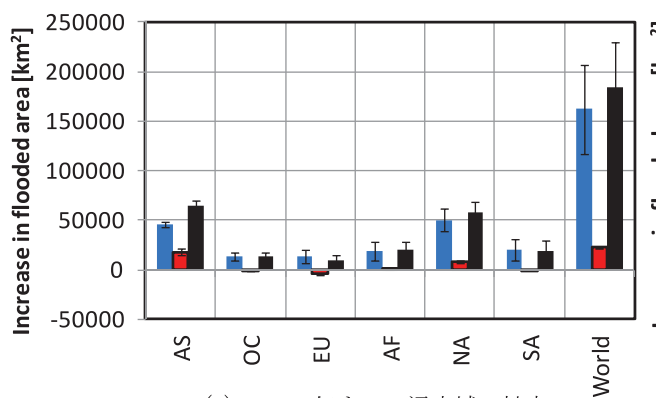

(a) 2100 年までの浸水域の拡大

Sea-level rise
$\square$ Change in Intensity of TC
$\square$ Population growth
$\square$ Sub_Total
$\square$ Total
AS:ASIA
OC: OCEANIA
EU:EUROPE
AF:AFRICA
NA:North AMERICA
SA:South AMERICA

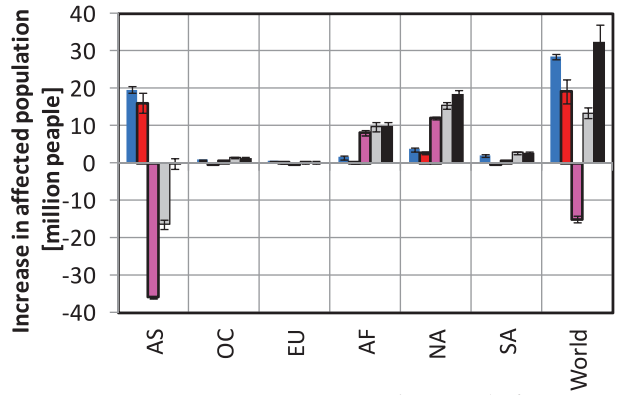

(b) 2100 年までの浸水域人口の増減
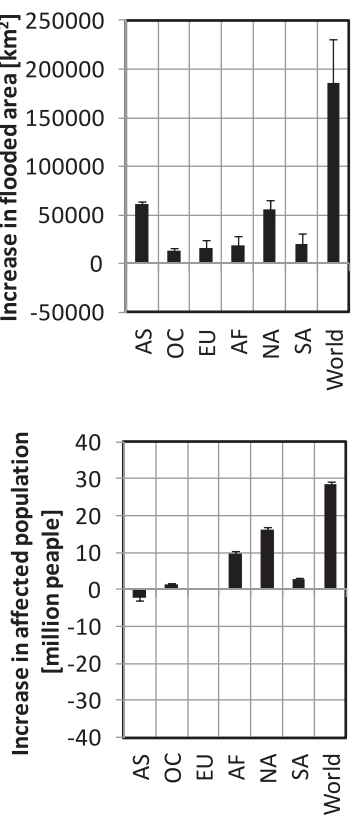

図-5 熱帯低気圧の勢力変化を含めた地球温暖化による沿岸域脆弱性評価結果

(右図は2100年までに中心気圧の低下を $10 \%$ 増した場合の結果)

気圧変化速度が将来気候で変化することを考慮して求 めた将来気候高潮は, 現在気候の高潮に比べアジア東岸 とメキシコ湾やアメリカ東岸で高くなる傾向が表れた. 熱帯低気圧の中心気圧の将来変化は, 全球の潜在的な高 潮浸水面積に $12 \%$ ほど影響する. 浸水域人口には, アジ アを中心にさらに大きく影響する結果となった。熱帯低 気圧の気候変化は, 海面上昇や人口成長と同程度の影響 は現気候台風の中心気圧低下からさらに $10 \%$ ほど低下さ せた場合と同程度で表れることも示した。

これらの結果は浸水域が拡大する範囲で, 特にアジア で人口が多いことを示唆している. 今後, 高潮浸水の詳 細分析を可能にするように, 将来の予測精度を向上させ, 高潮浸水域拡大に対する適応策の検討が重要である.

謝辞 : 本研究は文部科学省「21世紀気候変動予測革新プ ログラム，プログラム統括：松野太郎氏，西岡秀三氏」 による研究成果の一部である. 気候モデル出力結果は, 同プログラム、極端現象予測チーム（代表：気象研究所 鬼頭昭雄氏) の気象研究所（担当, 保坂征宏氏, 村上裕 之氏）と京都大学（代表：中北英一氏, 分担：間瀨肇氏, 安田誠宏氏）の研究成果を提供いただいた。ここに感謝 の意を表する。

\section{参 考 文 献}

加藤史訓 (2005)：高潮危険度評価に関する研究, 国土技術政 策総合研究所資料, No.275, 108p.

信岡尚道・三村信男（2009）：熱帯低気圧による全球の高潮と 沿岸脆弱性の推定, 土木学会論文集 B2 (海岸工学), 第 65 巻, pp.371-375.

安田誠宏・林 祐太・森 信人 · 間瀬 肇 (2010) : 地球温暖 化による高潮・高波推算に対応可能な確率台風モデル, 土木学会論文集B2 (海岸工学), 第66巻, pp.1241-1245.

Center for International Earth Science Information Network (CIESIN) : Country-level Population and Downscaled Projections based on the B2 Scenario, 1990-2100, 2002. [digital version]. Palisades, NY: CIESIN, Columbia University. Available at http://www.ciesin. columbia.edu/datasets/ downscaled (2009.1 参照).

Hasumi H., and E. Emori (2004) : K-1 Coupled GCM (MIROC) Description, K-1 Technical Report, CCSR/NIES/ FRCGC, 34p.

Hoozemans, F.M.J., M. Marchand and H.A. Pennekamp (1993) : A Global Vulnerability Assessment, Sea-Level Rise, Second Revised Edition, Delft Hydraulics, 184p.

Matsumoto, K., T. Takanezawa, and M. Ooe (2000) : Ocean Tide Models Developed by Assimilating TOPEX/POSEIDON Altimeter Data into Hydrodynamical Model: A Global Model and a Regional Model Around Japan, Journal of Oceanography, 56, pp.567-581.

Nicholls, R. J., M.J.F. Hoozemans and M. Marchand (1999) : Increasing flood risk and wetland losses due tu global sea-level rise: regional and global analyses, Global Environmental Change, 9, SS69- S87.

Yukimoto, S. and A. Noda (2001): Improvements of the Meteorological Research Institute Global Ocean-Atmosphere Coupled GCM (MRI-CGCM2) and Its Climate Sensitivity, CGER's Supercomputer Activity Reports, Vol.10, CGER-10542002, CGER/NIES, pp37-44. 